\title{
Hackerespaço: materialidade e corporeidade no Laboratório Hacker de Campinas.
}

\author{
Júlio Cortijo Eles*, Rodrigo Ferreira Toniol.
}

\begin{abstract}
Resumo
Essa iniciação científica teve como objetivo realizar uma etnografia do ciberespaço no hackerspace Laboratório Hacker de Campinas (LHC), trabalhando principalmente a questão da materialidade para a Antropologia e seu desdobramento teórico e prático na fisicalidade do hackerspace, partindo de uma discussão da Teoria-Ator-Rede de Bruno Latour.
\end{abstract}

Palavras-chave:

Materialidade, hackerspace, ciberespaço.

\section{Introdução}

O hackerspace mostrou-se um local extremamente fértil para a discussão proposta da materialidade, uma vez que esse campo têm sido revitalizado por outros pesquisadores através da introdução da Teoria-AtorRede (TAR), como é o caso do GrupCiber, que visa repovoar as etnografias já realizadas no ciberespaço ${ }^{1}$ através da introdução da TAR, uma vez que o enfoque dessas etnografias precisava de distanciar da exclusividade da ação humana, pois essa distinção prévia entre sujeitos e objetos, entre online e offline, humano e não-humano diminuía a observação de um espectro maior no campo da Antropologia da tecnologia.

\section{Resultados e Discussão}

A partir de uma "participação observante" 2, frequentando o LHC duas vezes por semana por alguns meses, partindo para visitas esporádicas, pude conhecer seus integrantes e observar a dinâmica do local. O espaço físico, aberto para qualquer interessado em conhecer, vive de doações e assim mantem-se independente. Lá dentro se é livre para utilizar a sala de eletrônica ou o quarto da marcenaria para dar andamento em qualquer projeto em mente, da mecânica à computação. Os hackers frequentadores estão dispostos a compartilhar todo o tipo de conhecimento, basta "chegar junto". Por essas questões foi possível compreender a importância do espaço físico do LHC, pois a grande maioria das relações acontecem no âmbito virtual, seja por Telegram ou Jitsi Meet, e por mais produtivas que sejam, o grande problema era a nãomaterialização dos projetos. As coisas não acontecem de verdade se não forem feitas com pessoas, com equipamentos, em um local interessante. A cultura hacker e maker é satisfeita quando esses agentes interagem entre si.

A localização central do LHC é significativa para o seu caráter democrático, mas o distanciamento físico também se mostra como um demarcador de temporalidade. Comunidades frequentemente acabam pela distância, tendo em vista que em uma cidade universitária como Campinas, há uma alta rotatividade de indivíduos especializados nas áreas, e isso tem influência direta na formação do corpo dessas comunidades. Graduações e pós-graduações, novas oportunidades de trabalhos, mudanças de cidade, são questões que ajudam a moldar os períodos de atividade do hackerspace. Durante um determinado espaço de tempo, é possível que estejam presentes apenas pessoas voltadas para a engenharia elétrica, fazendo com que projetos, eventos e discussões sejam focadas nessa área, enquanto em um segundo momento esses indivíduos darão lugar para outros hackers, começando um novo ciclo. O LHC possui momentos de atividade.

Por fim, é possível destacar uma transformação das técnicas corporais ${ }^{3}$ a partir da introdução do indivíduo na cultura hacker. Seja através da utilização de novas ferramentas para garantir sua privacidade na rede, a adaptação de equipamentos para sua maior segurança, começar a frequentar eventos voltados a essas comunidades, todas são ações advindas do convívio no hackerspace. A visão de transformar, mudar algo para além do seu desenho original logo se enraíza. Essa trajetória é similar a de muitos frequentadores do LHC. Seja conhecendo o local através da participação de eventos, por indicação de amigos que vão ao lugar ou por conta própria, é através dessa circulação de indivíduos com os mais diferentes conhecimentos que o hackerspace se torna um ambiente interessante.

\section{Conclusões}

Há uma parte fundamental da cultura hacker do LHC, sendo essa a materialização dos projetos com a participação ativa dos integrantes, tudo correlacionado em uma rede partindo do hackerspace, formando-o como um organismo complexo resultado das mais diferentes relações entre coisas. Assim como Latour destaca que "não há relação alguma entre o 'mundo material' e o 'mundo social' justamente porque essa divisão é um completo artefato" ", é possível notar que o real e virtual estão indissociavelmente intrincados, alinhando-se à simetria proposta pelo autor.

\section{Agradecimentos}

Gostaria de agradecer o CNPq pelo apoio, meu orientador Rodrigo Toniol e o Laboratório Hacker de Campinas.

${ }^{1}$ SEGATA, J. A Etnografia como Promessa e o "Efeito Latour" no Campo da Cibercultura. Ilha Revista de Antropologia, Florianópolis, v. 16, n. 2, dez. 2014 ${ }^{2}$ WACQAUNT, L. Corpo e alma: notas etnográficas de um aprendiz de boxe. Rio de Janeiro: Relume Dumará, 2002.

${ }^{3}$ MAUSS, M. As técnicas corporais. In: Sociologia e Antropologia. São Paulo:

Ubu Editora, 2017.

${ }^{4}$ LATOUR, B. Reagregando o Social. Salvador: Edufba, 2012; Bauru, São

Paulo: Edusc, 2012. 